\title{
The efficiency of spermatogenesis and the support capacity of Sertoli cells in Characiformes
}

\author{
Maira da Silva Rodrigues a, Diógenes Henrique de Siqueira-Silva ${ }^{\mathrm{b}}$, \\ Patrícia Postingel Quirino ${ }^{\mathrm{a}}$, Alexandre Ninhaus-Silveira ${ }^{\mathrm{c}}$, Rosicleire Veríssimo-Silveira ${ }^{\mathrm{c}}$ * \\ ${ }^{a}$ UNESP - Univ. Estadual Paulista, Faculdade de Engenharia de Ilha Solteira, Departamento de Biologia e Zootecnia, L.I.NEO - Laboratório de Ictiologia \\ Neotropical. Av: Brasil, Centro, No 56. Ilha Solteira, 15385000, São Paulo, Brazil \\ ${ }^{\mathrm{b}}$ UNIFESSPA - UNIVERSIDADE FEDERAL DO SUL E SUDESTE DO PARÁ - Instituto de estudos em Saúde e Biologicas - IESB, Faculdade de Ciências da Saúde e \\ Biologicas - FACISB, Folha 31, Quadra 07, Lote especial s/n - Nova Marabá - PA, CEP 68507-590, Brazil \\ ${ }^{\mathrm{c}}$ UNESP - Univ. Estadual Paulista, Campus de Ilha Solteira, Departamento de Biologia e Zootecnia, L.I.NEO - Laboratório de Ictiologia Neotropical, Av: Brasil, \\ Centro, No 56. Ilha Solteira, 15385000, São Paulo, Brazil
}

\section{A R T I C L E I N F O}

\section{Article history:}

Received 10 April 2017

Received in revised form

20 July 2017

Accepted 21 July 2017

Available online 27 July 2017

\section{Keywords:}

Fish reproduction

Germ cells

Spermatogenesis

Stereology

Testicular morphometry

\begin{abstract}
A B S T R A C T
This stereological analysis of the types of germ cells and the number of Sertoli cells per cyst in Astyanax altiparanae testes during spermatogenesis is the first such report in Characiformes. Testes of 25 male A. altiparanae were examined. Based on the number of spermatogonia B per cyst (469.2 \pm 9.92$)$, we estimated that spermatogonia undergo at least nine mitotic divisions before differentiating into primary spermatocytes. There are four spermatogonia types: undifferentiated spermatogonia $A^{*}$, undifferentiated spermatogonia, differentiated spermatogonia, and type B spermatogonia. The number of Sertoli cells increased gradually from $1.41 \pm 0.51$ in the single undifferentiated spermatogonium $A^{*}$ to $9.25 \pm 0.50$ in cysts of spermatocytes in the leptotene/zygotene stage, possibly related to greater complexity of cellular events during the meiotic stage. The number of germ cells rose dramatically from spermatogonia $\mathrm{A}$ $(1.0 \pm 0)$ to spermatogonia B $(469.2 \pm 9.92)$; however, the quantity of spermatocytes inside the cysts in the leptotene/zygotene stage decreased $(300.6 \pm 6.97)$ relative to spermatogonia $B$, representing a loss of approximately $36 \%$ of the former number of cells. This was probably the result of apoptosis, which promotes successful development of the remaining cells during sperm production. The support capacity of Sertoli cells increased gradually during spermatogenesis.
\end{abstract}

() 2017 Published by Elsevier Inc.

\section{Introduction}

The yellowtail tetra Astyanax altiparanae (Characidae), is a good biological model due to its tolerance of handling, small size, sexual maturity at four months, and intertidal spawning, especially for research associated with biotechnology and reproductive biology, making it valuable in Neotropical aquaculture [1-5].

Much available data regarding the spermatogenesis of A. altiparanae are concerned with morphological aspects $[3,6]$, but interest in morphometric and stereological analysis is increasing [7-10]. Such tools allow elucidation of cellular mechanisms

\footnotetext{
* Corresponding author.

E-mail addresses: maira.bio2012@gmail.com (M.S. Rodrigues), diogenessilva@ unifesspa.edu.br (D.H. Siqueira-Silva), patipostingel@gmail.com (P.P. Quirino), ninhaus@bio.feis.unesp.br (A. Ninhaus-Silveira), rosiverissimo@bio.feis.unesp.br (R. Veríssimo-Silveira).
}

involved in mitotic and meiotic events and the differentiation of germ cells to form hundreds of spermatozoa from a single spermatogonium. Stereology, the three-dimensional interpretation of two-dimensional cross-sections, can provide knowledge of the interaction between germline cells and Sertoli cells during spermatogenesis.

This study aimed to characterize the dynamics of germ cell and Sertoli cell interaction with respect to cyst type and to determine the number of spermatogonial generations, the magnitude of germ cell loss, and the support capacity of Sertoli cells during spermatogenesis of $A$. altiparanae.

\section{Materials and methods}

\subsection{Ethics}

Experimental procedures were conducted in accordance with 
the guidelines for care and use of animals in the laboratory of the University Estadual Paulista (UNESP-Ilha Solteira). The Committee of Ethics and Research of UNESP approved the protocol 006/2012/ CONCEA. All surgical procedures were performed after euthanasia of animals with $0.1 \%(\mathrm{w} / \mathrm{v})$ benzocaine in absolute ethanol.

\subsection{Animals and sampling}

Twenty-five sexually mature male A. altiparanae reared in inground tanks at the Hydrobiology Station Engenheiro Souza Dias (CESP) were used. Testes were removed, cut into transverse and longitudinal sections, and fixed in $4 \%$ paraformaldehyde and $2 \%$ glutaraldehyde in Sorensen's phosphate buffer $(0.1 \mathrm{M}, \mathrm{pH} 7.4)$ for at least $24 \mathrm{~h}$. Samples were dehydrated in increasing concentrations of ethanol and embedded in glycol methacrylate resin (Technovit 7100/historesin; Heraeus Kulzer, Wehrheim, Germany).

The samples were sectioned at $3.0 \mu \mathrm{m}$ and $2.0 \mu \mathrm{m}$ on a glass blade equipped microtome LEICA RM 2145 (Leica Instruments $\mathrm{GmbH}$, Nussloch Heidelberg, Germany) and stained with hematoxylin and eosin. Photography and histological analyses were completed with a Zeiss optical microscope equipped with an AxioCam-MRC5 camera (Carl Zeiss Microimaging $\mathrm{GmbH}$, Göttingen, Germany).

\subsection{Stereological analysis}

After identification and morphological description of the germ cells present in A. altiparanae spermatogenesis [6], the diameter of the cell nuclei was measured using Motic Images Plus 2.0 software. Nuclei in one-hundred spermatogonia and one-hundred spermatozoa and in 4.500 of each type of spermatocyte and spermatid were measured.

The number of these cells, as well as of Sertoli cells, arising from a single type A undifferentiated spermatogonium (Aind*) in cysts of final spermatids were counted (Table 1 and Fig. 1 ).

Samples were cut in approximately 24 serial sections of $3.0 \mu \mathrm{m}$ for spermatogonia and spermatocytes and $2.0 \mu \mathrm{m}$ for spermatids. The thickness of the sections was according to preliminary morphometry based on the diameter of the nucleus of each cell type (Table 1). As the largest spermatocytes (pachytene) had mean nuclear size of $5.33 \pm 0.43 \mu \mathrm{m}, 3.0 \mu \mathrm{m}$ sections ensure to cut only once in the central region of the nucleus of these cells. To assure counting each cell only once, nuclei were counted only when the central region of the nucleus was visible on the image. The same procedure was adopted for spermatids (Fig. 2). Five cysts for each of the mentioned cell types were counted per fish [11].

The selected cysts were those in which a clear delimitation of Sertoli cells was visible (Fig. 1). The analyses were conducted with an optical microscope (Axio Scope.A1; ZEISS) using Motic Images Plus 2.0 software.

Statistical analyses were conducted with one-way ANOVA followed by Tukey's test $(P<0.05)$.

\section{Results}

The types of germ cells in the testicular germinal epithelium of A. altiparanae were morphologically defined [6]. Type A undifferentiated spermatogonia, with nuclear diameter of $\sim 8 \mu \mathrm{m}$, and the final spermatids at $1 \mu \mathrm{m}$ were, respectively, the largest and smallest germ cells of the germ cell lineages (Table 1). Nucleus differences supported the identification and characterization of those cells for further stereological analysis of spermatogenesis.

Through successive mitotic division, a single spermatogonium A gave rise to cysts of spermatogonia B containing approximately $469 \pm 9.92$ cells that underwent at least nine divisions before their differentiation in the spermatocyte leptotene/zygotene stage. The cysts of spermatocytes at the leptotene/zygotene stage contained a smaller number of cells $(300.6 \pm 6.97)$ than did spermatogonia B (469.2 \pm 9.92 ), representing approximately $36 \%$ fewer cells than expected (Table 1 and Fig. 1). After two meiotic divisions, spermatocytes produced spermatids, which can be separated into three types in A. altiparanae (initial, middle, and final). The cysts of final spermatids contained, on average, 888 cells (Table 1 ).

The numbers of germ cells per cyst indicated a meiotic index of 3.0. This parameter is calculated as the ratio of the number of mature spermatids to the number of spermatocytes in the leptotene/zygotene stage. The spermatogenesis efficiency, expressed as a percentage calculated by the number of mature spermatids observed divided by the possible number, was approximately $43 \%$.

The number of Sertoli cells on the germ cysts increased gradually from a single cell closely linked with an Aind* $(1.41 \pm 0.51)$ to approximately ten cells $(9.25 \pm 0.50)$ involving spermatocytes in the leptotene/zygotene stage. At this stage, the number of Sertoli cells per cyst peaked, at approximately seven Sertoli cells per spermatid cyst. This was used to calculate the support capacity of the Sertoli cells, defined as the ratio of the number of germ cells to the number of Sertoli cells per cyst (Table 1 and Fig. 1).

\section{Discussion}

Recent studies of spermatogenesis in several fish species have considered only the morphologic aspects of the process [6,12-14]. However, for a deeper understanding of the mechanisms that regulate spermatogenesis, stereological analysis is an effective means of investigating parameters such as numbers of mitotic divisions, making it possible to estimate the quantity of spermatozoa

Table 1

Stereology of germ cells in Astyanax altiparanae.

\begin{tabular}{|c|c|c|c|c|}
\hline $\begin{array}{l}\text { Types of germ } \\
\text { cells }\end{array}$ & Germ cells per cyst ( $n$ ) & Sertoli cells per cyst(n) & Nucleus diameter $(\mu \mathrm{m})$ & Support capability of Sertoli cells \\
\hline SPG Aind.* & $1.0 \pm 0^{\mathrm{a}}$ & $1.41 \pm 0.51^{\mathrm{a}}$ & $7.67 \pm 0.63^{\mathrm{a}}$ & $0.709^{\mathrm{a}}$ \\
\hline SPG Aind. & $1.0 \pm .0^{\mathrm{a}}$ & $1.44 \pm 0.49^{\mathrm{a}}$ & $6.12 \pm 1.16^{\mathrm{b}}$ & $0.694^{\mathrm{a}}$ \\
\hline SPG Adif. & $2.4 \pm 0.75^{\mathrm{a}}$ & $2.13 \pm 0.40^{\mathrm{a}}$ & $4.55 \pm 2.16^{c}$ & $0.939^{\mathrm{ab}}$ \\
\hline SPG B & $469.2 \pm 9,92^{\mathrm{b}}[512]$ & $7.31 \pm 0.49^{b c}$ & $4.83 \pm 0.54^{\mathrm{c}}$ & $64.186^{\mathrm{d}}$ \\
\hline SPC L/Z & $300.6 \pm 6.97^{\mathrm{c}}[512]$ & $9.25 \pm 0.50^{\mathrm{d}}$ & $5.16 \pm 0.84^{\mathrm{c}}$ & $32.497^{\mathrm{bc}}$ \\
\hline SPC P & $298.4 \pm 6,99^{c}$ & $9.71 \pm 0.47^{d}$ & $5.33 \pm 0.43^{\mathrm{d}}$ & $30.731^{\mathrm{cd}}$ \\
\hline E1 & $910.8 \pm 20.47^{b}[2048]$ & $7.22 \pm 0.55^{c}$ & $2.54 \pm 0.42^{\mathrm{e}}$ & $126.149^{\mathrm{e}}$ \\
\hline E2 & $898.0 \pm 12.78^{b}[2048]$ & $6.41 \pm 0.50^{\mathrm{b}}$ & $1.38 \pm 0.53^{\mathrm{f}}$ & $140.094^{\mathrm{f}}$ \\
\hline E3 & $888.8 \pm 18.98^{\mathrm{b}}[2048]$ & $6.33 \pm 0.49^{b}$ & $1.31 \pm 0.19^{g}$ & $140.411^{\mathrm{f}}$ \\
\hline SZ & & & $1.02 \pm 0.16^{\mathrm{g}}$ & \\
\hline
\end{tabular}

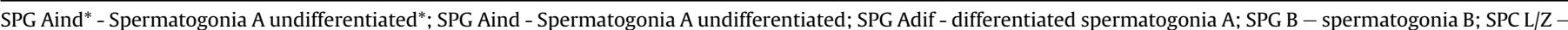
spermatocytes leptotene/zygotene; SPC P - spermatocytes in pachytene; E1 - early spermatid; E2-mid spermatid; E3-mature spermatid; SZ - spermatozoon.

${ }^{\mathrm{a}-\mathrm{g}}$ different letters indicate significantly different mean values $(\mathrm{P}<0.05)$. 


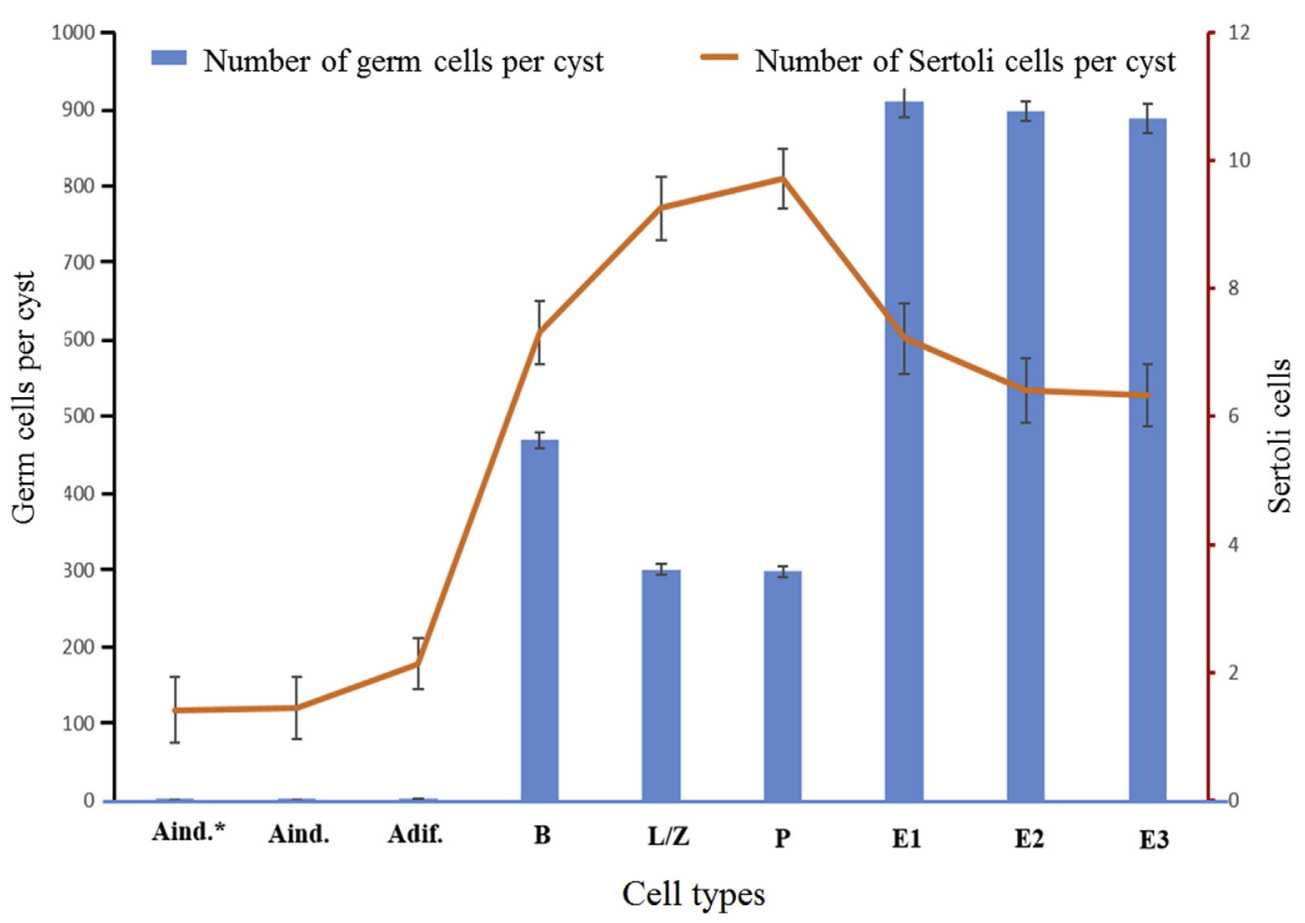

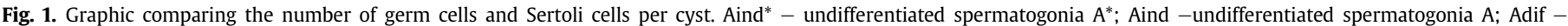

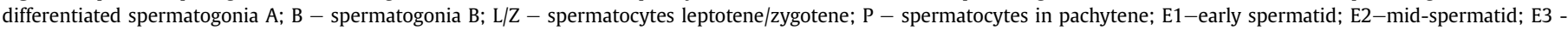
mature spermatid.

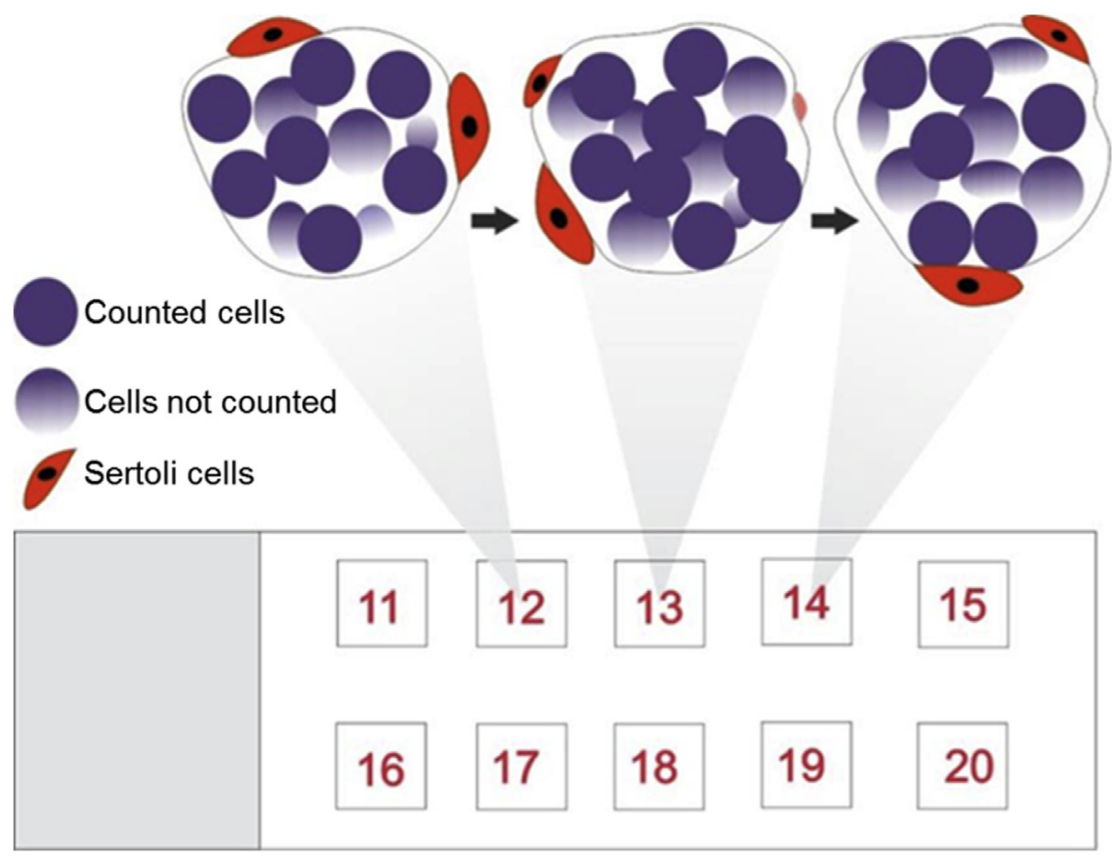

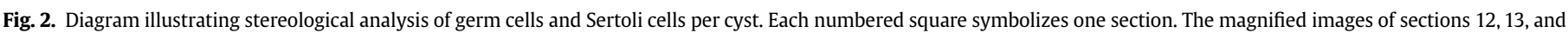
14 represent the same cyst at different depths. The germ cells were counted only when clearly defined.

produced by cysts at the completion of spermatogenesis. It can provide information to characterize the interaction between germ and Sertoli cells and the capacity of Sertoli cells to support the different types of germ cells, as well as to investigate the reduction in cell numbers, to reveal the stage at which the greatest apoptosis occurs.

The present study is one of few to investigate these areas, and A. altiparanae is one of few species in which spermatogenesis has been studied by stereology [15-18], allowing the characterization of cell lineages, such as the types of spermatids and the number of spermatogonial generations, that is essential to the understanding of spermatogenesis [19]. In addition to self-renewal and differentiation in daughter cells dedicated to forming spermatozoa, spermatogonia perform functions [19-22] such as the transmission of inherited characters, allowing, in association with cryopreservation and transplantation of germ cells, and gene banking for the 
recovery of threatened species and potential restoration of extinct species [23-25].

Spermatogonia lineages have been characterized by the number of mitotic divisions that the cells undergo before differentiating into spermatocytes $[24,26]$. This number is species-specific and seems to be related to the phylogenetic position occupied [26]. However, in contrast to the eight spermatogonial generations found in Hoplias malabaricus [27], which belongs to the same order as $A$. altiparanae, the number of generations in A. altiparanae was the same as that reported for Danio rerio [9] of Cypriniformes, which separated $\sim 127$ million years ago. Therefore, it is necessary to analyze a larger number of species to infer whether this variation occurs at the specific, family, or order level [26].

Sertoli cells also play a fundamental role in fish spermatogenesis. In addition to hormonal and nutritive support, their numbers regulate the quantity of germ cells during the process, limiting testes size and sperm production [28,29]. As in O. niloticus [7], the number of Sertoli cells per cyst in A. altiparanae gradually increased from the time it was closely associated with a single stem spermatogonium to the leptotene/zygotene stage of spermatocyte. In Poecilia reticulata and $D$. rerio, the increase in Sertoli cells continued to the beginning of spermiogenesis $[9,30]$. The greater number of Sertoli cells at the meiotic stage may be associated with the complexity of meiosis, a stage in which germ cells undergo multiple processes including nucleus division, genetic recombination, and apoptosis, leading to Sertoli cell involvement in phagocytosis of the resulting cell waste $[26,31]$.

The meiotic index and the reduction in cell numbers by $57 \%$ from type B spermatogonia to the completion of spermatogenesis show the spermatogenetic effectiveness of $43 \%$ in A. altiparanae. The reduction in cell numbers is directly related to the support capacity of Sertoli cells and seems to be essential, positively contributing to the quality of the generated spermatozoa [7,9]. A similar observation was reported for $H$. malabaricus [27].

Stereological study contributed to the understanding of spermatogenesis in the yellowtail tetra A. altiparanae, showing the complexity of this process by assessing morphometric parameters including support capacity of Sertoli cells, meiotic index, spermatogenesis efficiency, and cell number reduction. Stereology is recommended for descriptive studies of gametogenesis of other teleost species.

\section{Acknowledgments}

We are grateful to Usina Hidrelétrica Engenheiro Souza Dias (Jupiá- CESP) and Centro Nacional de Pesquisas e Conservação de Peixes Continentais (ICMBIO-CEPTA) for providing the specimens and to the Laboratory of Neotropical Ichthyology (L.I.NEO) for supporting this study. Financial support was from the Fundação de Amparo à Pesquisa do Estado de São Paulo (FAPESP) (process no 2013/24527-8; 2014/23379-8).

\section{Appendix A. Supplementary data}

Supplementary data related to this article can be found at http:// dx.doi.org/10.1016/j.theriogenology.2017.07.025.

\section{References}

[1] Orsi ML, Carvalho ED, Foresti F. Biologia populacional de Astyanax altiparanae. Garutti \& Britski (Teleostei, Characidae) do médio rio Paranapanema, Paraná, Brasil. Rev Bras Zool 2004;21. 207-2.

[2] Gimbo RY, Saita MV, Gonçalves AFN, Takahashi LS. Diferentes concentrações de benzocaína na indução anestésica do lambari-do-rabo-amarelo ("Astyanax altiparanae"). Rev Bras saúde Prod Anim 2008;9(2).

[3] Costa FG, Adolfi MC, Gomes CC, Jesus LWO, Batlouni SR, Borella MI. Testes of
Astyanax altiparanae: the Sertoli cell functions in a semicystic spermatogenesis. Micron 2014;61:20-7.

[4] Chehade C, Cassel M, Borella MI. Induced reproduction in a migratory teleost species by water level drawdown. Neotrop Ichtyol 2015;13:1.

[5] Siqueira-Silva DHD, Silva APS, Ninhaus-Silveira A, Verissimo-Silveira R. The effects of temperature and busulfan (Myleran) on yellowtail tetra Astyanax altiparanae (Pisces, Characiformes) spermatogenesis. Theriogenology 2015;84:1033-42.

[6] Rodrigues MS, Silva DHS, Quirino PP, Silveira AN, Silveira RV. Spermatogenesis in the yellowtail tetra Astyanax altiparanae: a histological analysis with emphasis to spermatogonial and spermatid types. Bol Inst Pesca 2015;41: 697-705 (Online).

[7] Vilela DAR, Silva SGB, Peixoto MTD, Godinho HP, França LR. Spermatogenesis in teleost: insights from the Nile tilapia (Oreochromis niloticus) model. Fish Physiol Biochem 2003;28:187-90.

[8] Santos LRS, Oliveira C. Morfometria testicular durante o ciclo reprodutivo Dendropsophus minutus (Peters) (Anura, Hylidae). Rev Bras Zool 2007;24: 64-70.

[9] Leal MC, Cardoso ER, Nobrega RH, Batlouni SR, Bogerd J, França LR, et al Histological and stereological evaluation of zebrafish (Danio rerio) spermatogenesis with an emphasis on spermatogonial generations. Biol Reprod 2009;81:77-187.

[10] Navarro RD, Matta SLP, Ribeiro Filho OP, Ferreira WM, Miranda DC, Pereira FKS. Morfometria e desenvolvimento gonadal em (Oreochromis niloticus) suplementada com vitamina E. Arch Zootec 2010;5:519-28.

[11] Nobrega RH, Batlouni SR, França LR. An overview of functional and stereological evaluation of spermatogenesis and germ cell transplantation in fish. Fish Physiol Biochem 2009;35(1):197-206.

[12] Veríssimo-Silveira R, Gusmão-Pompiani P, Vicentini CA, Quagio Grassiotto I. Spermiogenesis and spermatozoa ultrastructure in Salminus and Brycon, two primitive genera in Characidae (Teleostei: Ostariophysi: Characiformes). Acta Zoo 2006;87:305-13.

[13] Siqueira-Silva DHD, Vicentini CA, Ninhaus-Silveira A, Verissimo-Silveira R. Reproductive cycle of the Neotropical cichlid yellow peacock bass Cichla kelberi: a novel pattern of testicular development. Neotrop Ichthyol 2013;11: $587-96$.

[14] Chakrabarti P, Banerjee AS. Histological findings and seasonal distribution of different germ cells in the testicles of freshwater needle fish, Xenentodon cancila (Hamilton). Int J Fish Aquat Stud 2015;2(3):74-80.

[15] Nagahama Y. The functional morphology of teleost gonads. In: Hoar WS Randall DJ, Donaldson EM, editors. Fish physiol; 1983. p. 223-76.

[16] Alexandrino AC, Phan MT, Pinheiro EFG. Caracterização macroscópica e microscópica das gônadas do curimbatá, Prochilodus scrofa (Steindachner, 1881), durante o ciclo reprodutivo. Bolm Zool 1985;9:159-75.

[17] Reis RE, Kullander SO, Ferraris JRCJ. In: Alegre Porto, editor. Check list of the freshwater fishes of South and Central America; 2003. da PUCRS.

[18] Nóbrega RH, Lo Nostro FL, Grier Harry J, Quagio-Grassioto I. Cellular proliferation in fish male germinal epithelium. International Symposium on Animal Biology of Reproduction - from sex differentiation to reproductive biotechnology Anim Reprod 2006;3:199.

[19] De Rooij DG, Russell LD. All you wanted to know about spermatogonia but were afraid to ask. J Androl 2000;21:776-98.

[20] Morena AR, Boitani C, Pesce M, Felici M, Stefanini M. Isolation of highly purified type a spermatogonia from prepubertal rat testis. J Androl 1996;17: $708-17$.

[21] Nóbrega RH, Greebe C, De Kant HV, Bogerd J, França LR, Schulz RW. Spermatogonial stem cell niche and spermatogonial stem cell transplantation in zebrafish. Plos One 2010;5:e12808.

[22] Schulz RW, França LR, Lareyre JJ, Legac F, Chiarini-Garcia H, Nobrega RH, et al Spermatogenesis in fish. Gen Comp Endocrinol 2010;165:390-411.

[23] Okutsu T, Suzuki K, Takeuchi Y, Takeuchi T, Yoshizaki G. Testicular germ cells can colonize sexually undifferentiated embryonic gonad and produce functional eggs in fish. Proc Natl Acad Sci U. S. A 2006;103:2725-9.

[24] Nóbrega RH, Batlouni SR, França LR. An overview of functional and stereological evaluation of spermatogenesis and germ cell transplantation in fish. Fish physiol.biochem 2009;35:197-206.

[25] Lee S, Iwasaki Y, Shikina S, Yoshizaki G. Generation of functional eggs and sperm from cryopreserved whole testes. Proc Natl Acad Sci 2013;110(5): $1640-5$.

[26] Schulz RW, Nóbrega RH. Anatomy and histology of fish testis. In: Farrell AP, editor. Encyclopedia of fish physiology: from genome to environmentvol. 1. San Diego: Academic Press; 2011. p. 616-26.

[27] Bizzotto PM, Godinho HP. Morphometric evaluation of the spermatogenesis in traira Hoplias malabaricus (bloch) (Characiformes, Erythrinidae). Rev Bras Zool 2007;24(3):541-4.

[28] Sharpe RM, Mckinnell C, Kivlin C, Fisher JS. Proliferation and functional maturation of Sertoli cells, and their relevance to disorders of testis function in adulthood. Reprod 2003;125:769-84.

[29] Petersen CW. Sexual selection and reproductive success in hermaphroditic seabasses. Integr Comp Biol 2006;46:439-48.

[30] Billard R. La spermatogenèse de Poecilia reticilata. IEstimation du nombre de génerations goniales et rendement de la spermatogenése. Ann Biol Bioch Biophys 1969;9:251-71.

[31] Alberts B, Johnson A, Lewis J, Raff M, Roberts K, Walter P. Biologia Molecular da Célula. $5^{\text {a }}$ ed. Ed. Artmed. 2010. 